\title{
The various mechanisms of tricuspid regurgitation in patients with right ventricular leads: a case series
}

\section{Karlo Golubić* \\ Vlatka Rešković Lukšić \\ Irena Ivanac Vranešić Vojtjeh Brida}

University of Zagreb School of Medicine, University Hospital Centre Zagreb, Zagreb, Croatia

\begin{abstract}
KEYWORDS: echocardiography, tricuspid regurgitation, pacemaker, electrode. CITATION: Cardiol Croat. 2015;10(3-4):74. | DoI: http://dx.doi.org/10.15836/ccar.2015.74
\end{abstract}

ORCID: Karlo Golubić, http://orcid.org/0000-0003-0684-6333 • Vlatka Rešković Lukšić, http://orcid.org/0000-0002-4721-3236 • Irena Ivanac Vranešić, http://orcid.org/0000-0002-6910-9720 • Vojtjeh Brida, http://orcid.org/0000-0002-8191-3615

*ADDRESS FOR CORRESPONDENCE: Karlo Golubić, Klinički bolnički centar Zagreb, Kišpatićeva 12, HR-10000 Zagreb, Croatia. Phone: +385-1-2388-888. E-mail: karlo.golubic@gmail.com

|I|I|||||||||||||||||||||||||||||||||||||||||||||||||||||||||||||||||||||||||||||||||||||||||||||||||||||||||||||||||||||||||||||

Implantable device leads can cause tricuspid regurgitation (TR) when they interfere with leaflet motion. Patients may present with clinical symptoms of right-sided congestive heart failure (jugular venous distention, pulsatile liver, peripheral edema), although many are asymptomatic. The detection of severe tricuspid regurgitation by echocardiography may be missed because of acoustic shadowing from the pacemaker wires and suboptimal visualization of the regurgitant jet. ${ }^{1-3}$

The aim of this study was to present the various mechanisms through which ventricular leads may cause TR in real-life cases detected by echocardiography.

We describe five patients with new or worsening preexisting TR after the implantation of one or more right ventricular leads, their clinical presentation, diagnosis and treatment (Figure 1, Figure 2). The mechanisms of TR include lead adher-

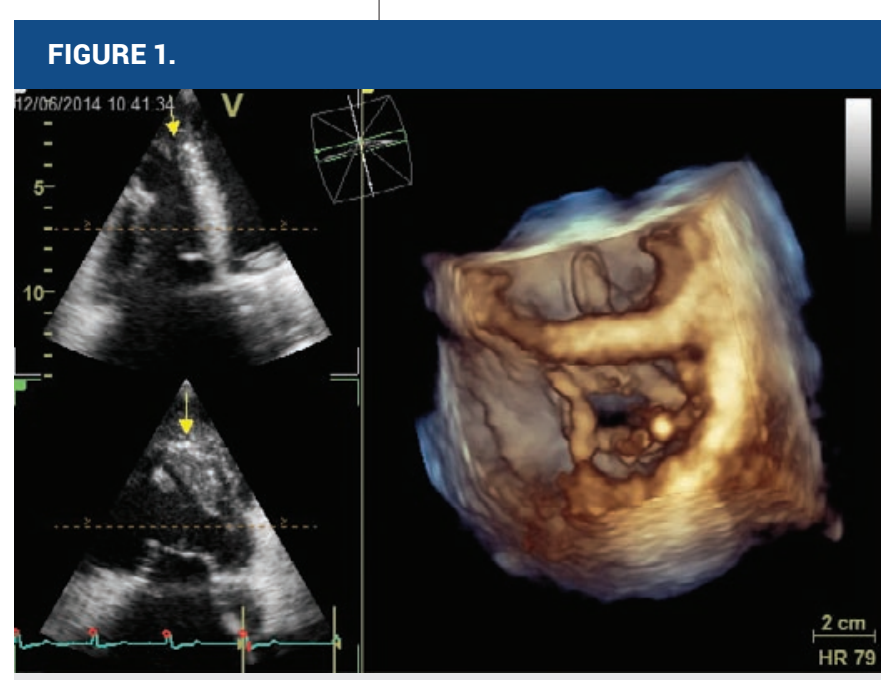

$3 D$ view of the malcoaptation of the tricuspid valve leaflets caused by a pacemaker lead.

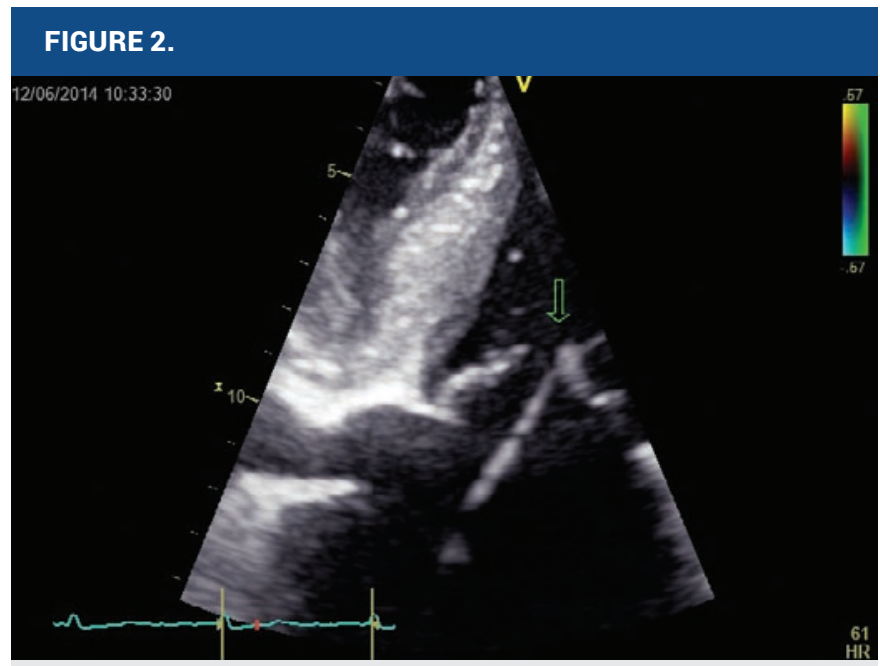

Apical four chamber view of the malcoaptation of the tricuspid valve leaflets caused by a pacemaker lead.
RECEIVED:

April 15, 2015

ACCEPTED:

April 20, 2015

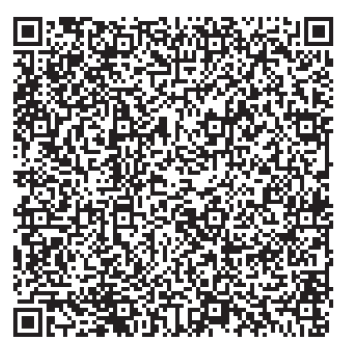

ence to the leaflets due to fibrosis and scar formation causing incomplete valve closure, valve obstruction caused by a lead placed in between leaflets, lead entrapment in the tricuspid valve apparatus, valve perforation or laceration by the pacemaker lead and annular dilatation of the valve.

CONCLUSION: TR should be suspected in patients with implantable device leads who develop new onset right heart failure. Echocardiography plays an important role in the diagnosis of device-related TR although it has limitations.



1. Al-Bawardy R, Krishnaswamy A, Bhargava M, Dunn J, Wazni O, Tuzcu EM, et al. Tricuspid regurgitation in patients with pacemakers and implantable cardiac defibrillators: a comprehensive review. Clin Cardiol. 2013;36(5):249-54. DOI: http://dx.doi.org/10.1002/clc.22104

2. Addetia K, Maffessanti F. Mediratta A, Yamat M. Weinert L. Moss JD, et al. Impact of implantable transvenous device lead location on severity of tricuspid regurgitation. J Am Soc Echocardiogr. 2014;27(11):1164-75. DOI: http://dx.doi.org/10.1016/j.echo.2014.07.004

3. Mediratta A, Addetia K, Yamat M, Moss JD, Nayak HM, Burke MC, et al. 3D echocardiographic location of implantable device leads and mechanism of associated tricuspid regurgitation. JACC Cardiovasc Imaging. 2014,7(4):337-47. DOI: http://dx.doi.org/10.1016/j.jcmg.2013.11.007 